\title{
FAKTOR RISIKO TRANSMISI VIRUS HIV PADA IBU HAMIL DI PAPUA
}

\author{
Alberthzon Kris Silo Rabrageri ${ }^{1}$, Risanto Siswosudarmo ${ }^{2}$, Soetrisno ${ }^{3}$
}

\begin{abstract}
Background: Human Immunodeficiency Virus (HIV) has been transmitted all over the world and attack people including pregnant women and their fetus. HIV-AIDS has become the main cause of maternal death. The transmission is started from Africa to Indonesia, specifically to Papua Island. In Papua, HIV is a serious threat for pregnant women's life because of its fast transmission, even faster from other regions in Indonesia. Until present, there has no research about HIV transmission on pregnant women in Papua Island.
\end{abstract}

Objective: To conduct analysis on risk factors related to HIV transmission on pregnant women in Papua Island.

Method: Cross sectional continued with retrospective cohort. Data was taken from medical record of all patients delivering in eight state-owned hospitals in Papua and West Papua provinces started from 1 January 2013 to 31 December 2013. Inclusion criteria were all pregnant women who delivered vaginally or by caesarean sections with HIV and non HIV diagnosis and had complete medical record data. Data being taken included mother's age when delivered the baby, mother's education, parents' social economic status, mother's ethnicity, parents' domicile, prematurity and infant's birth weight. The two research groups were HIV (+) and HIV (-) groups. Data were statistically analyzed using Pearson Chi Square for univarian and logistic regression for multivarian.

Result and Discussion: In Papua island, prevalence of pregnant women with HIV was $15.3 \%$, and mostly occurred in reproductive age ( $85.1 \%)$. The main transmission source was heterosexual (100\%). Univarian analysis found that mothers's age $<20$ years old when delivered the baby increase 1.12 times compared to $\geq 20$ years old but it's statistically insignificant $(p=0.53)$. Mothers education $\leq 9$ years increases the risk of HIV 1.4 times compared to mother's education $>9$ years $(p=0.01)$. The husband's low socioeconomic status increase the risk of 5.51 times compared with husband's high socioeconomic status $(p<0.01)$. The wife's low socioeconomic status increase the risk of 1.22 times, in which statistically insignificant $(p=0.14)$. Native Papuanese pregnant women has significantly 3.05 times higher risk for HIV transmission compared to non Papuanese $(p<0.01)$. Pregnant women's domicile in villages increase the transmission significantly 2.21 times compared to cities' domiciles $(p<0.00)$. Premature delivery increased HIV transmission by 1.7 times $(p<0.01)$. Low infant body weight increased the transmission by 1.64 times significantly $(p<0.01)$. Multivarian analysis showed that husband's low socioeconomic status, Papuanese ethnicity and domicile in villages are the most dominant factors influencing HIV transmission on pregnant women in Papua Island. Conclusion: Varied risk factors on HIV transmission resulted in the occurrence of HIV (+) cases in Papua Island, while the most dominant factors are husband with low socioeconomic status, Papua ethnicity and domicile in villages.

Keywords: HIV, risk factors, birthing mothers, Papua Island.

\footnotetext{
KSM Obgin RSUD Dok II Papua

Departemen Obstetri \& Ginekologi, Fakultas Kedokteran, Universitas Gadjah Mada, Yogyakarta

Departemen Obstetri \& Ginekologi, Fakultas Kedokteran, Universitas Sebelas Maret
} 


\begin{abstract}
ABSTRAK
Latar belakang: Human Immunodeviciency Virus (HIV) saat ini telah menyebar ke seluruh dunia, dan menyerang siapa saja termasuk ibu melahirkan dan janin yang dikandungnya. HIV-AIDS merupakan penyebab utama kematian ibu di seluruh dunia. Penyebaran HIV dimulai dari Afrika dan sampai ke Indonesia, secara khusus sampai ke seluruh Tanah Papua. Di Tanah Papua HIV merupakan ancaman serius bagi kelangsungan ibu melahirkan, karena penyebarannya sangat cepat, bahkan lebih cepat dari daerah lain di Indonesia. Sampai saat ini belum ada penelitian tentang HIV pada ibu melahirkan di seluruh Tanah Papua.
\end{abstract}

Tujuan: Melakukan analisis faktor risiko yang berhubungan dengan penularan HIV pada ibu melahirkan di Tanah Papua.

Metode: Cross sectional dilanjutkan dengan Kohort retrospektif. Data diambil dari rekam medis seluruh pasien yang melahirkan di delapan rumah sakit milik Pemerintah Provinsi Papua dan Papua Barat mulai 1 Januari 2013 sampai 31 Desember 2013. Kriteria inklusi semua ibu melahirkan vaginal dan seksio sesarea yang terdiagnosis HIV dan non HIV dan memiliki kelengkapan data rekam medis yang di perlukan serta lepas dari kriteria ekslusi. Data yang diambil meliputi umur ibu saat melahirkan, pendidikan ibu, sosial ekonomi ibu, sosial ekonomi suami, suku bangsa ibu, domisili, prematuritas serta berat badan bayi lahir. Dua kelompok penelitian yaitu HIV (+) dan HIV (-). Data dianalisis secara statistik menggunakan Pearson Chi Square untuk univariat dan regresi logistik untuk multivariat.

Hasil dan Pembahasan: Di Tanah Papua prevalensi ibu melahirkan dengan HIV 15.3\% (Cl 95\%), terbanyak pada usia reproduksi (85.1\%), sumber penularan utama heteroseksual (100\%). Analisis univariat mendapatkan bahwa umur ibu melahirkan $<20$ tahun meningkat 1.12 kali di banding $\geq 20$ tahun secara statistik tidak bermakna ( $p=0.53$ ). Pendidikan ibu $\leq 9$ tahun meningkatkan risiko kejadian HIV pada ibu melahirkan 1.4 kali di bandingkan $>9$ tahun $(p=0.01)$. Sosial ekonomi suami rendah meningkatkan risiko 5 , 51 kali di banding tinggi $(p<0.01)$. Sosial ekonomi istri rendah meningkatkan risiko 1.22 kali di banding tinggi, secara statistik tidak bermakna $(p=0.14)$. Ibu melahirkan bersuku asli Papua mempunyai risiko terkena HIV 3.05 kali dibanding non Papua, secara statistik bermakna $(p<0.01)$. Domisili ibu melahirkan di kampung meningkat 2.21 kali di banding kota, secara statistik bermakna $(p<0.01)$. Kejadian persalinan prematur meningkat 1.8 kali pada HIV (+) di bandingkan HIV (-) secara statistik bermakna $(p<0.01)$. Kejadian bayi berat badan lahir rendah meningkat 1.64 kali pada ibu melahirkan HIV (+) di banding HIV (-) secara statistik bermakna $(p<0.01)$. Analisa multivariat menunjukkan bahwa faktor sosial ekonomi suami yang rendah, suku bangsa Papua, serta domisili di kampung merupakan faktor dominan yang paling berpengaruh pada kejadian HIV pada ibu melahirkan di tanah Papua.

Kesimpulan: Berbagai faktor risiko penularan HIV menyebabkan munculnya kasus HIV (+) di Tanah Papua, yang merupakan faktor dominan adalah sosial ekonomi suami yang randah, suku bangsa Papua, serta domisili di kampung.

Kata kunci: HIV, Faktor risiko, ibu melahirkan, dan Tanah Papua

\section{PENDAHULUAN}

Human immunodeficiency virus (HIV) dan Acquired Immune Deficiency Syndrome (AIDS) telah diketahui sebagai kontributor utama kematian ibu diseluruh dunia. Ada 33.4 juta penduduk dunia yang tertular HIV/AIDS, 22.4 juta tinggal di Sub Sahara Afrika, 3.8 juta tinggal di Asia Tenggara dan 2 juta tinggal di Amerika Latin. Dari data diatas 16 juta adalah perempuan (47\%) dan 2.7 juta (6.2\%) adalah anak. Usia harapan hidup pada usia 15 tahun di negara dimana infeksi HIV/ 
AIDS sangat tinggi akan menurun dari 50 tahun menjadi 30 tahun. $^{1}$

Data yang dipublikasikan oleh Direktorat Jenderal Pengendalian Penyakit dan Penyehatan Lingkungan (Ditjen PP \& PL) Kementrian Kesehatan Republik Indonesia tentang Situasi Masalah HIV-AIDS Triwulan I (Januari-Maret) tercatat dari bulan Januari sampai dengan Maret 2014 jumlah kasus baru infeksi HIV dilaporkan sebanyak 6.626 kasus. Persentase infeksi HIV tertinggi dilaporkan pada kelompok umur 2549 tahun $(72,3 \%)$, diikuti kelompok umur 20-24 tahun (15\%), dan kelompok umur $\geq 50$ tahun (5, 8\%). Rasio HIV antara laki-laki dan perempuan adalah 1:1. Persentase faktor risiko HIV tertinggi adalah hubungan seks berisiko pada heteroseksual (55, 6\%), LSL (Lelaki Berhubungan Seks dengan Lelaki) (14, 7\%), dan penggunaan jarum suntik tidak steril pada penggunaan narkoba Suntik (penasun) (7\%). ${ }^{2}$

Situasi masalah HIV-AIDS sejak pertama kali ditemukan tahun 1987 sampai dengan Maret 2014, HIV-AIDS tersebar di 368 (72\%) dari 497 kabupaten/kota di seluruh provinsi di Indonesia. Provinsi yang pertama kali ditemukan adanya kasus HIV-AIDS adalah Provinsi Bali, sedangkan yang terakhir melaporkan adalah Provinsi Sulawesi Barat pada tahun 2011. ${ }^{2}$

Sampai dengan tahun 2005 jumlah kasus HIV yang dilaporkan sebanyak 859, tahun 2006 (7.195), tahun 2007 (6.048), tahun 2008 (10.362), tahun 2009 (9.793), tahun 2010 (21.591), tahun 2011 (21.031), tahun 2012 (21.511) dan tahun 2014 (6.266).Jumlah kumulatif infeksi HIV yang dilaporkan sampai dengan Maret 2014 sebanyak 134.053. Jumlah infeksi HIV tertinggi yaitu di DKI Jakarta (30.023), diikuti Jawa Timur (16.752), Papua (14.943), Jawa Barat (11.084) dan Bali (8.543). Sedangkan prevalensi kasus AIDS per 100.000 penduduk berdasarkan Provinsi, maka Provinsi Papua dan Papua barat adalah 583,34. ${ }^{2}$
Di Tanah Papua HIV-AIDS sudah menjadi ancaman yang serius bagi kelangsungan hidup seluruh rakyat Papua. Hal ini disebabkan karena penyebarannya sangat cepat, bahkan lebih cepat dari daerah-daerah lain di Indonesia. Kasus HIV/ AIDS di Tanah Papua pertama kali ditemukan di Kabupaten Merauke pada tahun 1992. Saat itu dilaporkan 6 kasus HIV/AIDS yang terdiri dari 2 warga negara Indonesia (WNI) yang berprofesi sebagai perempuan pekerja seks komersial dan 4 warga negara asing (WNA) yang berprofesi sebagai nelayan Thailand. Setahun kemudian, dilaporkan 49 kasus HIV dan 1 kasus AIDS. ${ }^{3}$

Data terakhir yang dilansir oleh Dinas Kesehatan Provinsi Papua dan Komisi Penanggulangan HIV/AIDS (KPA), penderita HIV sesuai data 31 September 2013 mencapai 15.577 HIV kasus yang ditemukan untuk 28 Kabupaten dan kota Jayapura. Namun ada 13 kabupaten yang belum melaporkan data pasien HIV, sehingga dipastikan jumlah penderita HIV akan bertambah jika laporan dari 13 kabupaten tersebut masuk. ${ }^{4}$

Data Survei Terpadu HIV Perilaku (STHP) tahun 2006 yang dilakukan oleh Badan Pusat Statistik dan Departemen Kesehatan Republik Indonesia menunjukkan bahwa di Provinsi Papua dan Papua Barat, penyakit HIV/AIDS telah menyebar ke $2,4 \%$ populasi umum yang jika ditinjau dari sisi epidemiologi angka ini menggambarkan suatu generalized epidemic. Angka ini, jika dihubungkan dengan jumlah penduduk Tanah Papua yang hanya sekitar 2.85 juta jiwa, berarti saat ini ada 68.400 jiwa di Tanah Papua yang terinfeksi. ${ }^{5}$

Usia terbanyak penderita HIV-AIDS di tanah papua adalah usia reproduksi 15-49 tahun yakni $71 \%$ dan $49 \%$ nya adalah perempuan. Ini berarti ada 3088 perempuan yang menderita HIV-AIDS di Provinsi Papua. Dan jika dihubungankan dengan usia reproduksi maka ada 2192 perempuan usia reproduksi di tanah papua yang menderita HIV- 
AIDS. Angka ini juga memberikan arti bahwa ada 2192 perempuan di Papua yang akan hamil atau sementara hamil atau telah melahirkan dan sementara menyusui anaknya. Selanjutnya, angka 2192 ini juga berarti ada 2192 bayi baru lahir yang mungkin akan tertular HIV dari ibunya. ${ }^{5}$

Tingginya kasus HIV/AIDS di Papua ternyata menimbulkan banyak permasalahan misalnya kinerja pelayanan kesehatan makin terbebani dan kebutuhan biaya kesehatan akan terus meningkat. Apabila upaya pencegahan dan penanggulangan tidak ditingkatkan, maka epidemi HIV-AIDS di tanah Papua akan menyebar makin luas di masyarakat umum, memperbesar beban sosial, memperparah kemiskinan dan berdampak buruk terhadap pembangunan.

Dari sisi klinis medis, HIV/AIDS di Papua juga akan memperburuk kondisi yang kesehatan yang memang telah buruk misalnya tingginya kematian ibu dan bayi, tingginya kejadian TBC, malaria dan gizi buruk. Dengan demikian kondisi ini akan menghambat semua upaya yang telah dilakukan guna meningkatkan kesejahteraan rakyat, upaya untuk mengejar ketertinggalan pembangunan, dan upaya pencapian MDGs di tanah Papua, bahkan yang lebih mengkhawatirkan adalah hilangnya satu generasi masyarakat asli Papua. ${ }^{6}$

Berbeda dengan cara penularan HIV/AIDS dibeberapa daerah di Indonesia yakni pengunaan jarum suntik pada pengguna Narkoba, maka di Provinsi Papua berdasarkan data Dinas Kesehatan Provinsi Papua bulan Desember 2010 penularannya 90\% didominasi oleh hubungan seksual tidak aman, dan $4 \%$ transmisi vertikal dari ibu ke bayi (perinatal). Jika dilihat dari keadaan ini maka upaya pemutusan mata rantai penularan HIV/AIDS di tanah Papua harus ditujukan pada perubahan perilaku seks yang tidak bertanggung jawab dan pencegahan penularan dari orang tua kepada bayi yang dikandungnya. ${ }^{6}$

Berdasarkan latar belakang penelitian diatas maka muncul permasalahan penelitian yaitu bagaimanakah factor risiko transmisi virus HIV dari ibu ke janinnya? Karena itu tujuan penelitian ini adalah mengetahui factor risiko transmisi virus HIV dari ibu ke janinnya.

\section{METODE}

Jenis penelitian yang digunakan adalah observasional Analitik, dengan menggunakan studi cross sectional dan dilanjutkan dengan kohort retrospektif. Penelitian ini dilakukan di RSU Dok II Jayapura, RSUD abepura Jayapura, RSUD Merauke, RSUD Wamena, RSUD Mimika, RSUD Sorong, RSUD Manokwari, dan RSUD FakFak, selama 1 tahun, dari tanggal 1 Januari 2013 - 31 Desember 2013. Selajutnya data tersebut dianalisis secara statistik dengan menggunakan Uji Analisis Regresi Logistik dan univariat dengan Pearson Chi-Square. Analisis statistik dilakukan dengan bantuan software SPSS for Windows versi 20.

\section{HASIL DAN PEMBAHASAN}

Penelitian ini dilakukan di delapan Rumah Sakit milik Pemerintah Provinsi Papua dan Papua Barat. Dasar pemilihan ke delapan rumah sakit ini adalah pertama, semua rumah sakit tersebut telah memasukan program Prevention of Motherto-Child Transmission (PMTCT) dan telah menjadi program di tiap-tiap rumah sakit sejak tahun 2008 dan kedua, kedelapan rumah sakit ini dapat menggambarkan pelayanan kesehatan di Tanah Papua, baik di dataran tinggi, dataran rendah dan pesisir pantai, dimana untuk menjangkau tempat penelitian $85 \%$ menggunakan tranportasi udara dan $15 \%$ menggunakan transportasi darat.

Berdasarkan data yang diperoleh dari delapan rumah sakit Pemerintah Provinsi Papua dan Papua Barat dari tanggal 1 Januari 201331 Desember 2013, jumlah ibu melahirkan ada 1316 orang dan ibu melahirkan yang HIV positif ada 202 orang. Prevalensi atau angka kejadian Ibu melahirkan dengan HIV positif pada delapan rumah sakit tersebut adalah $15,3 \%$ (CI 95\%). 
Pravelensi HIV pada ibu melahirkan jumlah ibu melahirkan ada 1316 orang dan menggambarkan tentang jumlah keseluruhan yang HIV positif ada 202 orang dengan sumber kasus HIV ibu melahirkan yang terjadi pd suatu utama penularan adalah heteroseksual (100\%). waktu tertentu di suatu wilayah (population Prevalensi atau angka kejadian Ibu melahirkan base). Berdasarkan data yang diperoleh dari dengan HIV positif pada delapan rumah sakit delapan rumah sakit Pemerintah di Tanah Papua tersebut adalah 15,3.

dari tanggal 1 Januari 2013-31 Desember 2013,

Tabel 1. Karakteristik Ibu melahirkan dengan HIV di delapan RS Pemerintah di Tanah Papua

\begin{tabular}{llcc}
\hline \multicolumn{1}{c}{ Variabel } & & $\mathrm{N}$ & $\%$ \\
\hline Umur ibu (tahun) & $<20$ & 30 & 14,9 \\
Pendidikan ibu (tahun) & $\geq 20$ & 172 & 85,1 \\
& $<9$ & 81 & 40,1 \\
Sosial ekonomi suami & $\geq 9$ & 121 & 59,9 \\
& Rendah & 186 & 92,1 \\
Sosial ekonomi ibu & Tinggi & 16 & 7,9 \\
& Rendah & 80 & 39,6 \\
Suku bangsa ibu & Tinggi & 122 & 60,4 \\
& Papua & 162 & 80,2 \\
Domisili & Non Papua & 40 & 19,8 \\
& Kampung & 44 & 21,8 \\
Paritas & Kota & 158 & 78,2 \\
& Primipara & 89 & 44,1 \\
Usia kehamilan (minggu) & Multipara & 113 & 55,9 \\
& $<37$ & 52 & 25,7 \\
Jenis Persalinan & $\geq 37$ & 150 & 74,3 \\
& Seksio sesarea & 98 & 48,5 \\
& Vaginal & 104 & 51,5 \\
\hline
\end{tabular}


Tabel 2. Hubungan antara faktor risiko dengan kejadian HIV pada ibu melahirkan

\begin{tabular}{lcccccc}
\hline Variabel & HIV (+) & HIV (-) & HIV $(+) \%$ & RR & $95 \% \mathrm{Cl}$ & $\mathrm{P}$ \\
\hline Umur ibu & & & & & & \\
$<20$ tahun & 30 & 147 & 16,9 & 1,12 & $0,79-1,60$ & 0.53 \\
$\geq 20$ tahun & 172 & 967 & 15,1 & 1 & & \\
\hline $\begin{array}{l}\text { Pendidikan ibu } \\
<9 \text { tahun }\end{array}$ & 81 & 344 & 19,1 & 1,40 & $1,09-1,81$ & 0.01 \\
$\geq 9$ tahun & 121 & 770 & 13,6 & 1 & & \\
\hline Sosial ekonomi suami & & & & & & \\
Rendah & 186 & 707 & 20,8 & 5,51 & $3,35-9,06$ & 0.01 \\
Tinggi & 16 & 407 & 3,8 & 1 & & \\
\hline $\begin{array}{l}\text { Sosial ekonomi istri } \\
\text { Rendah }\end{array}$ & 80 & 381 & 17,4 & 1,22 & $0,94-1,57$ & 0.14 \\
Tinggi & 122 & 733 & 14,3 & 1 & & \\
\hline $\begin{array}{l}\text { Suku } \\
\text { Papua }\end{array}$ & 162 & 589 & 21,6 & 3,05 & $2,19-4,23$ & 0.00 \\
Non Papua & 40 & 525 & 7,1 & 1 & & \\
\hline Domisili & & & & & & \\
Kampung & 44 & 103 & 29,9 & 2,21 & $1,66-2,95$ & 0.00 \\
Kota & 158 & 1011 & 13,5 & 1 & & \\
\hline
\end{tabular}

Tabel 2. menunjukan bahwa kelompok Umur kurang dari 20 tahun akan meningkatkan kejadian HIV pada ibu hamil sebesar 1.12 kali, namun hal ini tidak bermakna secara statistik. Sehingga bisa dikatakan umur ibu tidak mempengaruhi kejadian HIV dalam kehamilan $(p=0,53)$.

Usia penderita yang didominasi oleh usia reproduksi menunjukan bahwa perilaku seks berisiko telah dimulai pada usia yang sangat belia. Kondisi ini didukung oleh hasil penelitian Unicef Papua tahun 2003 tentang survei anakanak SMP dan HIV/AIDS di Papua. Dilaporkan bahwa $12 \%$ anak yang pernah melakukan hubungan seks, pertama kali dilakukan pada usia 13 - 15 tahun. Penelitian yang sama di lakukan oleh PSK Uncen pada tahun 2004 tentang Survei kaum muda (10 s/d 24 tahun) di luar Sekolah/ Kampus mendapatkan hasil bahwa hubungan seks pertama kali terjadi pada usia 17 tahun, bahkan ada yang melakukan pada usia 10 tahun. Dominasi usia reproduksi ini, tidak hanya di temukan pada ibu melahirkan penderita HIV/ AIDS, tetapi merupakan gambaran umum penyebaran HIV/AIDS di tanah Papua.

Pendidikan kurang dari 9 tahun akan meningkatkan risiko kejadian HIV pada ibu hamil sebesar 1,4 kali dibandingkan ibu dengan pendidikan yang cukup ( $>9$ tahun) ( $R R=1,40 ; 95 \%$ $\mathrm{Cl} 1,09-1,81)(p=0,01)$.

Idealnya, dengan semakin tingginya pendidikan seseorang maka pemahannya tentang dampak buruk dari penyakit ini semakin baik. Namun pada penelitian ini terlihat dengan jelas bahwa prevalensi tertinggi penderita HIV pada ibu melahirkan adalah mereka yang berpendidikan lebih dari 9 tahun (59,9\%). Pada analisis faktor risiko terlihat bahwa pendidkan kurang dari 9 tahun meningkatkan kejadian HIV pada ibu melahirkan sebesar $14 \%$.

Mengapa yang berpendidikan cukup baik malah menjadi golongan mayoritas penderita 
HIV/ AIDS? Limoa berpendapat mungkin karena HIV/ AIDS ini tidak berhubungan dengan tingkat kecerdasan atau skor Intelligence Quotient (IQ) seseorang, tetapi berhubungan dengan perilaku atau Emotional Intelligence (EQ). Seseorang yang memilki kecerdasan baik belum tentu memiliki perilaku yang baik pula. Oleh karena itu bisa dipahami mengapa HIV/ AIDS banyak menimpa kelompok yang berpendidikan cukup baik. Dengan kata lain, tingginya tingkat pendidikan tidak berhubungan dengan tingkat kejadian HIV/ AIDS. ${ }^{7}$

Ibu dengan suami yang status sosial ekonominya rendah mempunyai risiko terkena HIV dalam kehamilan 5,51 kali lebih besar dibandingkan ibu dengan suami yang status sosial ekonominya tinggi $(\mathrm{RR}=5,51 ; 95 \% \mathrm{Cl} 3,35$ $9,06)(p<0,01)$.

Wahyuningsih mengatakan hubungan antara tingkat HIV yang tinggi dan status sosial ekonomi rendah dapat dikaitkan dengan faktorfaktor yang biasanya terkait dengan risiko infeksi HIV pada heteroseksual yaitu penggunaan lem aibon, terkena penyakit infeksi menular seksual dan bergonta-ganti pasangan. Perilaku suami pengangguran di beberapa daerah di Papua adalah sering mengkonsumsi minuman keras, berkunjung ke lokalisasi prostitusi, melakukan hubungan seks tanpa pengaman, pulang tengah malam dan memukul istri bila tidak melayani hasrat seksnya. Perilaku tersebut di atas bias menjadi awal mula penularan HIV. Data Centerfor Disease Control and Prevention mengungkapkan tingkat infeksi HIV di kalangan heteroseksual (perilaku seks normal) berpenghasilan rendah di 24 kota di Amerika, 10 sampai 20 kali lebih besar dari populasi umum. ${ }^{8}$

Sosial ekonomi istri rendah meningkatkan risiko kejadian HIV sebesar $22 \%$, namun tidak bermakna secara statistik $(p=0,14)$. Penelitian yang dilakukan oleh Oktariana, mengatakan bahwa angka kejadian HIV pada IRT yang sosial ekonmimya rendah, disebabkan karena karena dua hal: pertama, IRT lebih cendrung berada di rumah sehingga pengetahuan mereka tentang HIV/AIDS sangat kurang jika dibandingkan mereka yang bekerja di luar rumah. Kedua: kelompok masyarakat ini umumnya berada didaerah yang minim informasi sehingga pengetahuan mereka terhadap HIV/AIDS sangat kurang dibanding daerah yang kaya informasi. Kondisi ini sungguh memprihatikan terutama dari aspek kesehatan reproduksi. Seorang perempuan Papua terinfeksi HIV harus mampu mendidik dan menjaga kesehatan anak dan seisi keluarga, sebagai pelaku utama penghasil pendapatan keluarga, melahirkan keturan baru tetapi disisi lain dia harus menjaga kesehatan dirinya sendiri agar tidak mati karena HIV. ${ }^{9}$

Suku Papua mempunyai risiko terkena HIV dalam kehamilan 3,05 kali lebih besar dibandingkan suku non Papua (pendatang) $(R R=3,05 ; 95 \% \mathrm{Cl} 2,19-4,23)(p<0,01)$.

Ibu melahirkan yang berdomisili di kampung juga mempunyai risiko terkena HIV 2, 21 kali lebih besar dibandingkan ibu melahirkan yang berdomisili di kota $(\mathrm{RR}=2,21 ; 95 \% \mathrm{Cl} 1,66-2,95)$ $(p<0,01)$.

Morin mendapatkan data tentang perilaku seksual di daearah $X$ di Provinsi Papua sebagai berikut. Frekuensi hubungan seks luar nikah $65 \%$. Laki-laki mempunyai pasangan seks lebih dari 1 sebanyak 35\%. Pernah memliki lebih dari 10 pasangan seks sebanyak $8,7 \%$. Pernah melakukan hubungan seks dengan lebih dari 50 perempuan sebanyak 50\%, dan 53\% lakilaki pernah melakukan hubungan seks dengan perempuan usia $\leq 19$ tahun. Juga ditemukan pemaham tentang seks antri dimana $17 \%$ lakilaki pernah melakukan hubungan seks antri, $37 \%$ perempuan pernah melakukan seks antri. Kejadian seks antri ini dapat terjadi di desa 
dan kota. Seks antri biasanya berhubungan dengan uang, alkohol dan obat bius dan tidak menggunakan kondom. ${ }^{9}$

la menggambarkan bahwa pola seksual umum di Papua yakni :

1. Pedesaan, dilakukan sembunyi-sembunyi, melalui perantara, sesama pasangan dari satu suku, hubungan seks terjadi pada peristiwaperistiwa umum (pesta), seks berhubungan dengan mobilitas tinggi, cenderung terjadi di luar batas masyarakat adat dan ada seks antri.

2. Pinggiran, dilakukan sembunyi-sembunyi, melalui perantara, seks berhubungan dengan mobilitas tinggi, cenderung terjadi dalam batas masyarakat adat dan di luar, seks aktif, seks oral dan anal, hubungan seks dengan berbagai suku dan golongan sosial, tidak beranggapan sebagai pekerja seks, sering mabuk dan isap aibon, seks antri

3. Perkotaan, seks terbuka, aktif, antri, langsung, tanpa batas masyarakat adat, berbagai golongan sosial, oral seks, anal seks, terorganisir, jalanan, bar, panti pijat, hotel dan lokalisasi, homoseksual, imbalan uang, minuman keras, mengaku sebagai pekerja seks, mobilitas tinggi.

Untuk mengetahui variabel yang paling berpengaruhi terhadap kejadian Infeksi HIV maka dilakukan analisis Regresi logistik sebagai berikut:

Tabel 3. Analisis regresi logistik variabel yang paling berpengaruh terhadap kejadian HIV pada ibu melahirkan

\begin{tabular}{|c|c|c|c|c|}
\hline \multirow{2}{*}{ Variabel } & \multirow{2}{*}{$\operatorname{Exp}(B)$} & \multicolumn{2}{|c|}{$95 \%$ C.I } & \multirow[t]{2}{*}{$P$} \\
\hline & & Lower & Upper & \\
\hline \multicolumn{5}{|c|}{ Umur ibu (tahun) } \\
\hline$<20$ & 1,18 & 0,75 & 1,86 & 0,47 \\
\hline$\geq 20$ & 1 & & & \\
\hline \multicolumn{5}{|c|}{ Pendidikan ibu (tahun) } \\
\hline$\leq 9$ & 1,35 & 0,96 & 1,89 & 0,82 \\
\hline$>9$ & 1 & & & \\
\hline \multicolumn{5}{|c|}{ Sosial ekonomi suami } \\
\hline Rendah & 6,46 & 3,79 & 11,02 & 0,00 \\
\hline Tinggi & 1 & & & \\
\hline \multicolumn{5}{|c|}{ Sosial ekonomi istri } \\
\hline Rendah & 0,92 & 0,66 & 1,30 & 0,65 \\
\hline Tinggi & 1 & & & \\
\hline \multicolumn{5}{|l|}{ Suku } \\
\hline Papua & 3,37 & 2,31 & 4,91 & 0,00 \\
\hline Non Papua & 1 & & & \\
\hline \multicolumn{5}{|l|}{ Domisili } \\
\hline Kampung & 2,46 & 1,61 & 3,77 & 0,00 \\
\hline Kota & 1 & & & \\
\hline
\end{tabular}


Tabel 5. menunjukan bahwa pada analisis multivariat regresi logistic, variabel yang paling berpengaruh terhadap kejadian HIV pada ibu melahirkan adalah sosial ekonomi suami yang rendah, suku dan domisili.

Berdasarkan hasil tersebut, sosial ekonomi suami yang rendah akan memberikan peningkatan risiko ibu terkena HIV dalam persalinan sebesar lebih dari 6, 46 kali dibandingkan dengan ibu yang mempunyai suami dengan sosial ekonomi yang tinggi $(\mathrm{RR}=6,46 ; 95 \% \mathrm{Cl} 3,79-11,02)$.

Ibu melahirkan yang mempunyai suku bangsa Papua serta berdomisili di kampung juga memberikan peningkatan risiko terjadinya HIV dalam persalinan sebesar 3, 37 kali dan 2, 46 kali lebih besar dibandingkan ibu pendatang (non Papua) dan ibu yang berdomisili di perkotaan (RR 3, 37; 95\% Cl 2, 31-4, 91 dan RR 2, 46; 95\% Cl 1, $61-3,77)$.

Umur ibu, pendidikan ibu, serta sosial ekonomi ibu tidak berpengaruh terhadap peningkatan risiko terjadinya HIV dalam persalinan, meskipun pada analisis bivariat sebelumnya pendidikan memberikan risiko peningkatan kejadian HIV sebesar 1, 4 kali.

\section{KESIMPULAN DAN SARAN}

Kejadian infeksi HIV pada ibu melahirkan lebih tinggi pada kelompok umur $\geq 20$ tahun, sosial ekonomi suami dan istri yang rendah, suku bangsa Papua, dan domisili di kampung. HIV meningkatkan angka kejadian prematuritas dan BBLR. Faktor yang paling berpengaruh meningkatkan kejadian HIV (+) di Tanah Papua adalah: Sosial ekonomi suami yang rendah, Suku Papua, dan Domisili di kampung. Saran yang dapat diberikan berdasarkan penelitian ini adalah (1) Dinas Kesehatan Provinsi Papua harus mengalokasikan dana khusus dari Provinsi, sehingga ada dana Abadi yang tersedia untuk membiayai semua kebutuhan rumah sakit umum daerah di tingkat Kabupaten dan Distrik, sehingga bisa mengadakan promotif pencegahan HIV pada ibu hamil berdasarkan hasil penelitian risiko, jika memungkinkan diusahakan dana dari Jaminan Kesehatan Nasional (2) memperkenalkan pelajaran HIV-AIDS sejak SD dan sampai ke SMU melalui pelajaran intra/ekstra kurikuler, untuk meningkatkan pengetahuan anak sejak usia dini tentang bahaya HIV-AIDS dan cara pencegahannya (3) Gereja, tokoh adat, tokoh Agama bekerjsama dengan Pemerintah Daerah dan LSM peduli HIV/AIDS untuk melakukan penyuluhan sampai ke pelosok tanah Papua dan sosialisasi secara terus-menerus kepada masyarakat tentang apa itu HIV/AIDS, cara penularanya, bagaimana mencegahnya, termasuk berperilaku sex aman supaya masyarakat mengerti dan bisa menghindari diri dari penyakit HIV/AIDS.

\section{DAFTAR PUSTAKA}

1. World Health Organization (WHO)/Joint United Nations Programme on HIV/AIDS (UNAIDS). HIV In Pregnancy: A Review. WHO/UNAIDS: Geneva 1999. [internet] 1999. [cited: 20 Desember 2013] Available from: http://whqlibdoc.who.int/hq/1999/ WHO_CHS_RHR_99.15.pdf

2. Dirjen PP \& PL Kementrian Kesehatan Republik Indonesia. Laporan perkembangan HIV-AIDS di Indonesia Triwulan I Tahun 2014. [internet] 2014. [cited: 20 juli 2014] Avaliable from: http://www. spiritia.or.id/Stats/StatCurr.php?lang=id\&gg=1

3. Komisi Penanggulangan AIDS Nasional. Laporan Triwulan Enam (Q6) KPA Provinsi Papua Barat Periode Oktober - Desember 2011. [internet] 2011. [cited: 24 Juni 2014] Avaliable from: http://www. kpan.or.id/narasi/20120124155633.docx

4. Anonymous. 15.577 Kasus HIV untuk 28 Kabupaten di Provinsi Papua. [internet] 2014. [cited: 24 Juni 2014] Avaliable from: http://suluhpapua.com/ read/2014/01/17/15-577-kasus-hiv-untuk-28kabupaten-di-provinsi-papua/

5. Irmanigrum Y, Priyono JB, Syahboedin I et al. 2007. Dalam: Ahnaf A, ed. Situasi Perilaku Berisiko dan Prevalensi HIV di Tanah Papua - Hasil STHP di Tanah Papua. BPS \& Kemenkes RI, Jakarta: [internet] 
2007. [cited: 15 Juli 2014] Avaliable from: http:// siteresources.worldbank.org/INTINDONESIA/ Resources/Publication/PapuaHIV_bh.pdf

6. Komisi Penanggulangan AIDS Provinsi Papua dan Papua Barat. 2008. Kepemimpinan Kuat dan Bijaksana untuk Percepatan Pencegahan dan Penanggulangan HIV dan AIDS di Tanah Papua, Papua.

7. Limoa RM. 2010. Profil Ibu Hamil dengan HIV Positif di BLU RS dr. Wahidin Sudirohusudo Makassar Periode 1 Januari 2005 - 31 Desember 2009. Makassar: Fakultas Kedokteran Universitas Hasanuddin.
8. Wahyuningsih M. 2014. Masyarakat Miskin yang Kena HIV 20 Kali Lebih Banyak. [internet] 2011. [cited: 20 Juli 2014] Avaliable from: http://health. detik.com/read/2011/08/12/113540/1702236/76 3/masyarakat-miskin-yang-kena-hiv-20-kali-lebihbanyak?o8833health.

9. Sumule S. 2011. Gambaran Epidemiologi Klinik Kehamilan Dengan Hiv Pada Beberapa Rumah Sakit Di Provinsi Papua Dan Papua Barat. Tesis PPDS II Obstetri dan Ginekologi Sosial Fakultas Kedokteran Universitas Padjadjaran. Bandung. 